\title{
Knowledge, beliefs and sources of information of HIV among students of a Tertiary Institution in Nigeria
}

\author{
Joseph A. Oluyemi ${ }^{\star}$, Joseph A. Adejoke ${ }^{2}$, Olokoba L. Bukola ${ }^{3}$, Adekeye \\ Deborah $^{1}$, Popoola Gbenga ${ }^{4}$ \\ ${ }^{1}$ Department of Sociology, University of Ilorin, Nigeria. ${ }^{2}$ Department of Microbial Pathology, University of Medical \\ Sciences, Ondo, Nigeria. ${ }^{3}$ Department of Ophthalmology, University of Ilorin Teaching Hospital, Ilorin, Nigeria. \\ ${ }^{4}$ Department of Psychiatry, Federal Teaching Hospital, Ido, Nigeria. \\ Correspondent author: Joseph A. Oluyemi, E. mail: josepholuyemi1@gmail.com
}

(Received 6 November 2018; Accepted 25 February 2019; Published 2 April 2019)

Abstract - Two out of three new HIV infections occurring globally each day occurs in sub-Saharan African in which Nigeria belongs. Its prevention however, is based on the knowledge of its transmission in which people are predisposed to. Unfortunately, the school environment has a high risk for the infection because of its vulnerability to high sexual risk behaviours which increases likelihood of HIV transmission. This study aimed at assessing the knowledge, beliefs and sources of information of HIV among students in the study area. The cross-sectional survey was conducted at an off-campus student community in Ilorin, north-central Nigeria. Primary data was collected through administration of structured questionnaire to 292 participants selected through multistage non-probability sampling method. Result revealed that, (84.2\%) of the participants have the knowledge that a healthy looking person can have HIV, $(88.7 \%)$ are knowledgeable of the fact that, HIV virus weakens the immune system of an infected person while, $(82.2 \%)$ know that HIV can be transmitted through unprotected sex. A total of (81.2\%) of the participants identified fever as the symptom of HIV while $(77.7 \%)$ identified safe sex as preventive measure. The highest source of information of HIV in the study is the media, $(68.2 \%)$ getting informed via health talk, followed closely by television (66.4\%).On participants' beliefs on HIV, (63.7\%) strongly disagree that HIV is a myth while (36.6\%) strongly agree that HIV can be cured with prayers. Statistical significant relationship (where p value $<0.05$ ) was found between the age of participants and knowledge of HIV, between all the sources of information and knowledge of HIV while only school, health talk and television were found to be significantly related with beliefs of participants. The study concluded that participants have high knowledge of HIV although froth with misconceptions that stems from the belief held about the disease.

Keywords: HIV, Knowledge, Asymptomatic, Beliefs, Media, Misconception 


\section{Introduction}

Sub-Saharan African where Nigeria is a country constitutes about $12 \%$ of the world population (Avert 2016). More than 70 percent of the global burden of HIV infection is found in this region with 10 countries within this subset of people, Nigeria inclusive, accounting for about $80 \%$ of all people living with HIV globally. Of the estimated 6,000 new infections that occur globally each day, two out of three are in sub-Saharan Africa hence effective control of the infection in sub-Saharan Africa has the likelihood of impacting positively on the global infection burden (Avert 2016).

Since the index case was recorded in Nigeria in 1986, HIV has spread widely among the inhabitants affecting all age group and ethnicity though at varying degrees. Affected majorly is adolescent female, young adults and teenagers aged 15-24 (Centers for Disease Control and Prevention 2015). At the initial stage, the disease is usually asymptomatic but as the infection progresses, the immune system is gradually and progressively overwhelmed allowing opportunistic infections and tumors to manifest in the infected individual (World Health Organization 2015).

HIV has resulted in considerable morbidity and mortality in human, markedly reducing the nation's workforce when adults are affected. Its toll on health care system as providers of care and public spending to finance its management cannot be overemphasized. Despite the relative importance of this disease entity, the proportion of individuals with a comprehensive knowledge of HIV transmission is still very low. There is also a significant disparity in HIV knowledge depending on place of abode, gender and level of education. In addition, irrespective of the huge investment of the government in voluntary HIV counseling and testing services, the utilization of this service in most African countries is quite low despite it being free. For example, only $11 \%$ of adults in 45 countries in sub-Saharan Africa received HIV testing in 2009. Also, only one-fourth of the 125 million pregnant women in low- and middle-income countries in 2009 received HIV testing (WHO/UNAIDS/UNICEF 2010)

Awareness of health risks is basic to disease prevention and health promotion. The goal of prevention in the context of HIV is to avoid or minimize the risk of transmission of HIV from an infected person to an uninfected person. But despite this, HIV prevention measures currently recommended at the individual and community 
levels are based on our knowledge of how HIV can be transmitted from person to person. It is a common thinking that what people know affects the way they behave. Behavioral patterns like how aggressive they are in the search for information, Brucks (1985) rate and extent of assimilation of new knowledge Graesser \& Glenn (1982); Johnson \& Edward (1984), choice processes, Bettman \& Whan (1980), information processing strategies, Fiske et al. (1983), problem solving processes, Sweller (1988) and perceptual processes (Obermiller \& John 1984).

HIV can be transmitted from an infected person to another through sexual activities unprotected sex and non-sexual activities such as sharing of sharp objects like hypodermic needle, unscreened blood transfusion as well as mother to child transmission during pregnancy (Liesl \& Mark 2013). Currently, HIV has no known cure but infected persons can be placed on Antiretroviral Therapy (ART) to make them live longer, live a healthier life and also avoid transmission of the infection to other people (Markowitz 2007). Hence the need to focus on health communication strategies in its prevention and control, aimed at increasing awareness of risk factors, mode of transmission of the disease and its effect on the infected (Markowitz 2007; Aids Info 2017).

Regrettably, the spread of HIV among people has continued to rise globally especially among young people (Oppong-Asante \& Oti-Boadi 2013). This high-risk group is said to account for 60 percent of the new infections in many countries within the region (World Bank 2002; Avert 2016). Unsafe sexual practices among this age group have been identified as one of the critical pathways for the transfer of the virus (Cote et al. 2004). It is therefore not surprising that sexual transmission is the commonest mode of transmission of HIV in the sun-Saharan region, accounting for approximately $90 \%$ of all infections and $80 \%$ of all new infections (National Agency for Control of AIDS 2012, 2014).

In Nigeria, HIV epidemic is spreading at a disturbing rate with sero-prevalence rates increasing from 0.9 percent in 1990 to 1.8 percent in 1992, 3.8 percent in 1994, 4.5 percent in 1996 and 5.4 percent in 1999, 2.9\% in 2010 (National Action on AIDS 2014). A study conducted in Kwara State, North-Central Nigeria on HIV epidemiology and impact analysis revealed that, young people between the ages of 15-19 constitute the highest age group living with HIV/AIDS (National Agency for Control of AIDS 2012). Further evidence has also shown a higher prevalence in urban dwellers than their rural dwelling counterpart, especially among young individuals in schools NACA (2009) as 
the school environment is presumed to provide fertile grounds for high sexual risk behavior which increases the likelihood of HIV transmission (Adefuye et al. 2009; Abiodun et al. 2014).

While researches on knowledge of HIV among students in tertiary institutions in Nigeria have been over flogged, researches on knowledge of HIV among students in host communities of tertiary institutions are relatively dearth. It is against this milieu that this study is being conducted. The study aims at assessing participants' knowledge, beliefs and sources of information of HIV in the study area. This is imperative in determining how adequately informed they are as a guide to preventive and control measures that need be put in place to reduce the prevalence of the HIV among students especially in the school community.

\section{Methodology}

The cross-sectional survey was conducted among University of Ilorin students living at Oke-Odo, Ilorin, Kwara State, and north-central Nigeria. Oke-Odo is a student host community situated close to the main Campus of the University of Ilorin and a preferred location of the off-campus resident of most students of the institution due to its proximity to the school. It is a mixed community of indigenous residents and students characterized by several student hostels and business activities. Informed consent was retrieved from intending participants. Consenting participants were sampled using multi-stage non-probability sampling method by which purposive sampling method was used to select the student community then; cluster sampling method was used to identify a major bus terminus from where students are conveyed to and fro school in the community and a convenience sampling method employed to select participants for the study.

A total of 292 consenting participants were included in the survey out of the 320 questionnaires distributed in the study representing $91.2 \%$ return rate. Bio data of participants including age, gender, religion and ethnic background were collected using a self-administered questionnaire which contained closed and open ended questions. Information on knowledge of risk factors, mode of transmission, clinical presentation, causes, treatment modality and preventive measures, beliefs as to the origin of disease and the sources of information on HIV was also collected using the questionnaire. Data 
was presented in frequency tables and percentages while formulated hypotheses were tested using chi-squared statistical tool.

\section{Results}

Of the 292 students sampled, 165 (56.5\%) were males while 127 (43.5\%) were females. One hundred and forty-seven of the participants (50.3\%) were aged below 20 years. Many were not married $(90.1 \%)$ and the predominant religion practiced was Christianity (60.3\%). Two hundred and twelve (72.6\%) participants are Yoruba and 80 (27.4\%) are from other major tribes in Nigeria namely Hausa and Ibo (Table 1).

Table 1: Socio-demographic variables of Participants

\begin{tabular}{ll}
\hline Socio-demographic variables & $\begin{array}{c}\text { Frequency } \\
\mathbf{n}(\%)\end{array}$ \\
\hline Age group (years) & \\
$<20$ & $147(50.3)$ \\
$20-24$ & $107(36.6)$ \\
$25-29$ & $30(10.3)$ \\
$\geq 30$ & $8(2.7)$ \\
Gender & \\
Male & $165(56.5)$ \\
Female & $127(43.5)$ \\
& \\
Marital status & \\
Single & $263(90.1)$ \\
Married & $29(9.9)$ \\
& \\
Religion & \\
Christianity & $176(60.3)$ \\
Islam & $114(39.0)$ \\
Traditional & $2(0.7)$ \\
& \\
Ethnic Background & \\
Yoruba & \\
Ibo & $212(72.6)$ \\
Hausa & $43(14.7)$ \\
Others & $21(7.2)$ \\
\hline Researchers' Survey, 2017 & $16(5.5)$ \\
\hline
\end{tabular}

Concerning basic knowledge on HIV (Table 2), 246 (84.2\%) participants are of the opinion that HIV status is not a function of an individual's physical look as a 
healthy looking person can be infected, 180 (61.6\%) of the participants are certain that HIV has no cure, while 155 (53.1) knows what the abbreviation "HIV" means. Furthermore, on the types of the virus in existence, 205 (70.2\%) participants knows that there are two types the virus and $259(88.7 \%)$ of the participants knows that its pathogenic mechanism is to weakens the immune system of an infected person. On disease progression, $234(80.1 \%)$ knows that it is possible to have HIV for many years without progressing to AIDS.

Table 2: Participants Basic Knowledge of HIV

\begin{tabular}{ll}
\hline Variable & $\begin{array}{l}\text { Frequency/ (\%) } \\
\text { n(\%) }\end{array}$ \\
\hline An healthy looking person can have HIV & \\
Yes & $246(84.2)$ \\
No & $46(15.8)$ \\
& \\
HIV has no cure & $180(61.6)$ \\
Yes & $112(38.4)$ \\
No & \\
& \\
Knowledge of full meaning of HIV & $155(53.1)$ \\
Correct & $137(46.9)$ \\
Wrong & \\
There are two types of HIV, HIV 1 and HIV 2 & \\
Yes & $205(70.2)$ \\
No & $87(29.8)$ \\
HIV weakens the immune system of the infected person & \\
Yes & $259(88.7)$ \\
No & $33(11.3)$ \\
HIV is the virus that leads to AIDS & \\
Yes & \\
No & $252(86.3)$ \\
It is possible to have HIV for years without progressing to & \\
AIDS & \\
Yes & \\
No & $234(13.7)$ \\
Researchers' Survey, 2017 & $58(19.9)$ \\
\hline
\end{tabular}

Assessing participant's knowledge on mode of transmission of HIV in table 3, majority $(82.2 \%)$ of the participants identified unprotected vagina sex as a mode of transmission, followed by vertical transmission from mother to child (80.5\%). Two hundred and twenty one $(75.7 \%)$ participants thinks infection is from transfusing blood, 
$218(74.2 \%)$ participants identified sharing of sharps while $213(72.9 \%)$ thinks infection is transmitted when infected individual have multiple sexual partner. HIV is reportedly transmitted through sharing of bathing soap and towel by $32(11.0 \%)$ of the participants while $23(7.9 \%)$ believes transmission can be through handshake and $18(6.2 \%)$ said it can be transmitted to another person by hugging (Table 3).

Table 3: Knowledge on mode of transmission, symptoms and preventive measures of HIV

\begin{tabular}{|l|l|}
\hline Variable & Frequency/ (\%) \\
\hline Mode of Transmission of HIV & \\
\hline Unprotected vaginal sex & $240(82.2)$ \\
\hline From mother to child & $235(80.5)$ \\
\hline Blood transfusion & $221(75.7)$ \\
\hline Sharing of infected needles & $218(74.7)$ \\
\hline Multiple sex partners & $213(72.9)$ \\
\hline Sharing tooth brush & $163(55.8)$ \\
\hline Anal sex & $152(52.1)$ \\
\hline Oral sex & $105(36.0)$ \\
\hline Through kissing & $82(28.1)$ \\
\hline Sharing bathing soap & $32(11.0)$ \\
\hline Sharing towels & $32(11.0)$ \\
\hline Handshake & $23(7.9)$ \\
\hline Hugging an infected person & $18(6.2)$ \\
\hline Symptoms of HIV & $237(81.2)$ \\
\hline Fever & $229(78.4)$ \\
\hline Weight loss & $182(62.3)$ \\
\hline Headache & $154(52.7)$ \\
\hline Low blood & $150(51.4)$ \\
\hline Coughing & $123(42.1)$ \\
\hline Body rash & $120(41.1)$ \\
\hline Muscle pain & $97(33.2)$ \\
\hline Joint aches and pains & $82(28.1)$ \\
\hline Drowsiness & $79(27.1)$ \\
\hline Swollen glands & $69(23.6)$ \\
\hline Sore throat & $65(22.3)$ \\
\hline Diahoerea & $48(16.4)$ \\
\hline stomach aches & $227(77.7)$ \\
\hline HIV Preventive Measures & $224(76.7)$ \\
\hline Avoid casual sex & $196(67.1)$ \\
\hline Use of condoms & $190(65.1)$ \\
\hline Sterilize needles and sharp objects before use & $160(54.8)$ \\
\hline Abstinence from sex & \\
\hline Be faithful to one sex partner & \\
\hline Researchers' Survey, 2017 & \\
\hline
\end{tabular}

Symptoms of HIV respondents are aware of include fever (81.2\%), weight loss $(78.4 \%)$ head ache $(62.3 \%)$, shortage of blood (52.7\%), coughing (51.4\%), stomach upset (16.4\%) and body rash (42.1\%). On how HIV transmission can be prevented, avoidance of casual sex is a preventive measure according to $227(77.7 \%$ ) respondents, 
this was followed closely by the use of condoms during sexual intercourse (76.7\%) and sterilizing needles and sharp objects before use (67.1\%). Other identified preventive measures are abstinence from sex $(65.1 \%)$ and faithfulness to one sex partner $(54.8 \%)$.

Beliefs held by participants on the cause and origin of HIV (Table 4) include believe that HIV/AIDS is a myth and does not exist (13), HIV is a black man disease (10), HIV is a poor man's disease (5), HIV is a punishment from God for the sin of man (35). Furthermore, (69) thinks HIV can be used to afflict someone while (54) respondents are of the opinion that they can never be infected with the virus even if exposed. Curative effect of herbs on the infection is believed by (75), similar to the belief of (187) in the curative power of fasting and prayers.

Table 4: Participants Beliefs on HIV

\begin{tabular}{llllll}
\hline & $\begin{array}{l}\text { Strongly } \\
\text { agree } \\
\mathbf{n}(\boldsymbol{\%})\end{array}$ & $\begin{array}{l}\text { Agree } \\
\text { Beliefs }\end{array}$ & Undecided & Disagree & $\begin{array}{l}\text { Strongly } \\
\text { disagree } \\
\mathbf{n}(\boldsymbol{\%})\end{array}$ \\
\hline $\begin{array}{l}\text { HIV is just a myth and does not } \\
\text { exist }\end{array}$ & $5(1.7)$ & $7(2.4)$ & $10(3.4)$ & $84(28.8)$ & $186(63.7)$ \\
HIV is a black man disease & $0(0.0)$ & $10(3.4)$ & $8(2.7)$ & $80(27.4)$ & $194(66.4)$ \\
HIV is a poor man's disease & $1(0.3)$ & $4(1.4)$ & $10(3.4)$ & $78(26.7)$ & $199(68.2)$ \\
$\begin{array}{l}\text { HIV is a punishment from God for } \\
\text { man's sin }\end{array}$ & $10(3.4)$ & $25(8.6)$ & $31(10.6)$ & $73(25.0)$ & $153(52.4)$ \\
$\begin{array}{l}\text { HIV can be used to afflict a person } \\
\text { I can never be infected with the } \\
\text { disease even if I have contact with }\end{array}$ & $12(4.1)$ & $42(14.4)$ & $30(10.3)$ & $110(37.7)$ & $98(33.6)$ \\
the virus & & & & & \\
HIV can be cured with herbs & $38(13.0)$ & $37(12.7)$ & $105(36.0)$ & $74(25.3)$ & $38(13.0)$ \\
$\begin{array}{l}\text { HIV can be cured with prayers and } \\
\text { Fasting }\end{array}$ & $107(36.6)$ & $80(27.4)$ & $40(13.7)$ & $31(10.6)$ & $34(11.6)$ \\
\hline
\end{tabular}

Researchers' Survey, 2017

The source of information of HIV (Table 5) includes health talk (68.2\%), television (66.4\%), Hospital (59.6\%) and radio (59.6\%). Other source of information includes friend (41.4\%) and family members (34.2\%). Relating socio-demographic variable with knowledge about HIV, age was found to significantly influence knowledge while other variables like sex, religion, tribe and marital status were not significant influence on knowledge. 
Table 5: Sources of Information on HIV

\begin{tabular}{|l|l|}
\hline Sources of Information & $\begin{array}{l}\text { Frequency } \\
\mathbf{n}(\boldsymbol{\%})\end{array}$ \\
\hline Health talk & $199(68.2)$ \\
\hline Television & $194(66.4)$ \\
\hline School & $185(63.4)$ \\
\hline Hospital & $174(59.6)$ \\
\hline Radio & $174(59.6)$ \\
\hline Newspaper and Magazines & $155(53.1)$ \\
\hline Internet & $151(51.7)$ \\
\hline Parents & $143(49.0)$ \\
\hline Friend & $121(41.4)$ \\
\hline Family members & $100(34.2)$ \\
\hline
\end{tabular}

Researchers' Survey, 2017

\section{Test of Hypotheses}

H01: There is no significant relationship between socio-demographic variables of participants, beliefs and knowledge of HIV.

H02: There is no significant relationship between sources of information of participants, beliefs and knowledge of HIV.

H01: Relationship between socio-demographic variables and beliefs about HIV

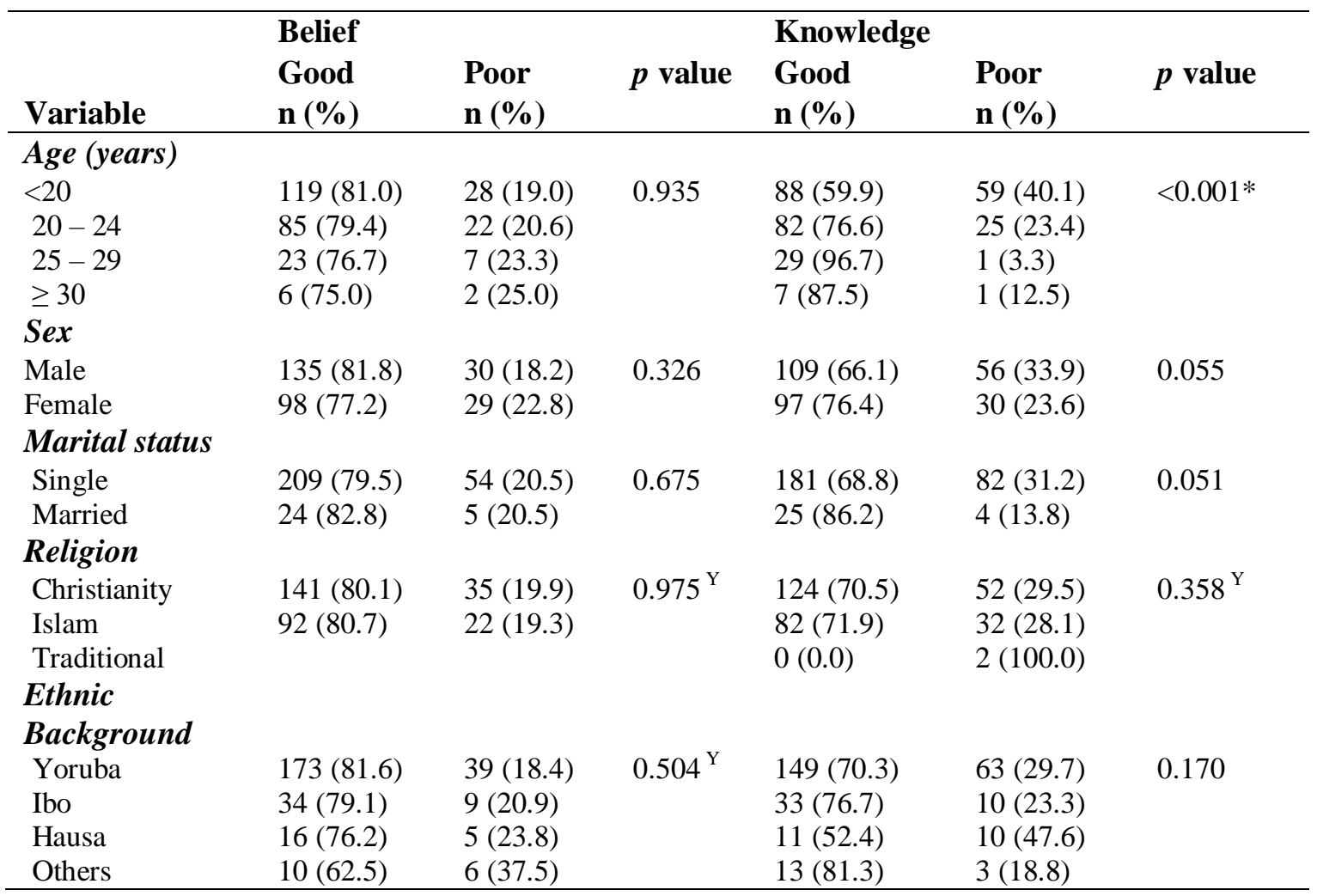

NB: Chi squared test used; *: $p$ value $<0.05$ 
H02: Relationship between source of information, belief and knowledge

\begin{tabular}{lllllll}
\hline & $\begin{array}{l}\text { Belief } \\
\text { Good } \\
\text { n }(\%)\end{array}$ & $\begin{array}{l}\text { Poor } \\
\text { n(\%) }\end{array}$ & p value & $\begin{array}{l}\text { Knowledge } \\
\text { Good } \\
\mathbf{n}(\boldsymbol{\%})\end{array}$ & $\begin{array}{l}\text { Poor } \\
\text { n }(\%)\end{array}$ & $\boldsymbol{p}$ value \\
Variable & $123(79.4)$ & $32(20.6)$ & 0.842 & $117(75.5)$ & $38(24.5)$ & $0.049^{*}$ \\
\hline Magazine/Newspaper & $123(81.5)$ & $28(18.5)$ & 0.464 & $131(86.8)$ & $20(13.2)$ & $<0.001^{*}$ \\
Internet & $113(79.0)$ & $30(21.0)$ & 0.747 & $112(78.3)$ & $31(21.7)$ & $0.004^{*}$ \\
Parent & $75(75.0)$ & $25(25.0)$ & 0.141 & $88(88.0)$ & $12(12.0)$ & $<0.001^{*}$ \\
Family members & $157(84.9)$ & $28(15.1)$ & $0.005^{*}$ & $163(88.1)$ & $22(11.9)$ & $<0.001^{*}$ \\
School & $96(79.3)$ & $25(20.7)$ & 0.870 & $106(87.6)$ & $15(12.4)$ & $<0.001^{*}$ \\
Friends & $144(82.8)$ & $30(17.2)$ & 0.126 & $156(89.7)$ & $18(10.3)$ & $<0.001^{*}$ \\
Hospital & $166(83.4)$ & $33(16.6)$ & $0.024^{*}$ & $163(81.9)$ & $36(18.1)$ & $<0.001^{*}$ \\
Health talk & $162(83.5)$ & $32(16.5)$ & $0.026^{*}$ & $153(78.9)$ & $41(21.1)$ & $<0.001^{*}$ \\
Television & $141(81.0)$ & $33(19.0)$ & 0.522 & $134(77.0)$ & $40(23.0)$ & $0.003^{*}$ \\
Radio & & & & & &
\end{tabular}

NB: Chi squared test used; *: $p$ value $<0.05$

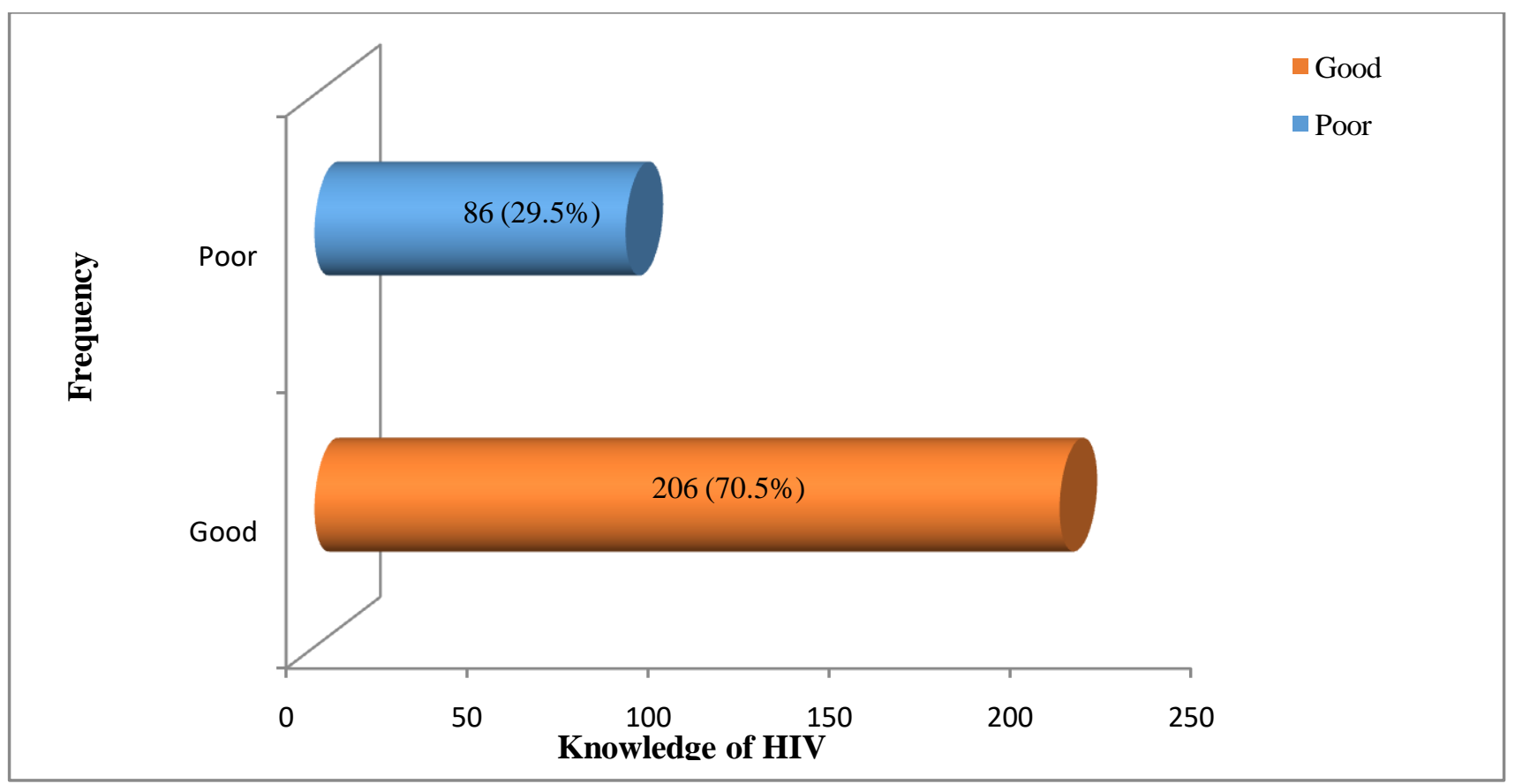

Fig. 1 Bar Chart Showing Knowledge of HIV

\section{Discussion}

This study assessed extensively, knowledge, beliefs and sources of information of HIV among students of University of Ilorin, sampling the opinion of those residing offcampus at a community located near the university. The study showed that participants have high knowledge of HIV (See figure 1) similar to the findings of Odua \& Akanle 
(2008) from selected government owned universities in South-West Nigeria and Abiodun et al. (2014) among undergraduates in a private University in the country which confirmed a high knowledge of HIV among students of tertiary institution.

The finding also is consistent with what was reported by Jose et al. (2011) in Guinea from a study involving students of tertiary institutions in Guinea and differs from the finding of Asante \& Oti-Boadi (2013) in Ghana which showed an inconsistent knowledge on HIV among undergraduates as participants were less knowledgeable about causative agents of HIV. This may be due to the higher prevalence rate of the infection in the countries where high knowledge is demonstrated for they are likely to have heard about the infection, seen cases or even have infected family members and friends. The media in such locations are likely to be agog with enlightening programmes and information on its identification, prevention, control and treatment such that a higher proportion of the population will be informed to some extent.

However, despite participants being highly informed about the infection, the authenticity of the information is queried as some had wrong information resulting in misconceptions about the disease. This misconstrued idea can stem from culture and tradition of the land as well as religious teachings. A sizeable number of participants believe that HIV can be cured through prayers and fasting, mirroring the high religious inclination of the people in the country. This finding is consistent with the finding of the previous study conducted by Ebeniro (2010) which asserts the significance of cultural beliefs on the knowledge of HIV among students in tertiary institutions in Rivers State, South-South Nigeria. The study also corroborates the result of Odua \& Akanle (2008) among undergraduates of four universities on South-West Nigeria which further highlights the significance of beliefs on what an individual knows about HIV, reiterating the strong influence of cultural beliefs and traditional practices on health of people in the Nigerian Society.

Health talk, being the commonest source of information on HIV reported in this study is in tandem with the findings of Harding et al. (1999) in a study conducted among students from tertiary institutions in South-West Nigeria and the report of Abiodun et al. (2014) which sampled the opinion of undergraduates in a private owned university where the media accounted for the highest source of information. This result further confirms the strong relationship between the media and health information as confirmed in several studies (Obisesan et al. 2005; Oye-Adeniran et al. 2006). 
While no statistical significant relationship was found between sociodemographic variables of participants and beliefs of participants in the study, a statistical significant relationship was found between knowledge of HIV and age of participants. This is consistent with the findings of the study conducted by Ezeonyido (2016) among undergraduates in Nigeria which suggested a significant relationship between knowledge of HIV and age of participants. The result also confirms earlier study conducted by Ogini et al. (2015) in which a significant relationship was found between knowledge of HIV and age of participants. In addition, all the sources of information identified in the study were significantly related to the knowledge of HIV among participants while only school, health talk and television were found to be significantly related to beliefs of participants on HIV in the study.

\section{Conclusion}

The study showed that participants have high knowledge on HIV even though froth with various misconceptions. The information were sourced mostly from the media, specifically health talks by health professionals and the level of knowledge is dependent on the age of participants and not sex, marital status, religion and tribe of participants. However, none of the demographic variables of participants in the study were significantly related with the participants' beliefs in the study while, age of participants was found to be significantly to knowledge of participants on HIV in the study. In addition the sex distribution of participants in the study was not found to be statistically related to both belief and knowledge of HIV. And while all the sources of information identified in the study were significantly related with the knowledge of HIV, only school, health talk and television were found to be significantly related with beliefs of participants in the study.

\section{Recommendations}

The study recommends widespread dissemination of adequate information on HIV among students of institution of higher learning in Nigeria to ensure adequate knowledge of the disease among students of institution of higher learning in Nigeria. The study also recommends community based enlightenment programmes channeled towards informing the public on the knowledge of HIV, especially in host communities of tertiary institutions where students reside and risky sexual behaviours may be prevalent. Enlightenment programmes on HIV by relevant agencies via media channels such as television and radio is also strongly recommended. 
Conflicts of Interest: The authors declare no conflict of interest.

\section{References}

Abiodun O., Sotunsa J., Ani F., Jaiyesimi E. 2014. Knowledge of HIV/AIDS and predictors of uptake of HIV counseling and testing among undergraduate students of a privately owned university in Nigeria. BMC Research Notes.

DOI: 10.1186/1756- 0500- 7-639. Retrieved from:

http://bmcresnotes.biomedcentral.com/articles/10.1186/1756-0500-7-639.

Adefuye A.S., Abiona T.C., Balogun J.A., Lukobo-Durrell M. 2009. HIV sexual risk behaviors and perception of risk among college students: Implications for planning Intervention. BMC, Public Health. Retrieved from http:/www.biomedcentral.com/1471-2458/9/281.

Adinma J.I.B., Nwosu B.O. 2005. Family planning knowledge and practice among Nigerian women attending an antenatal clinic. Advcontracept. 11(4):335-344.

Retrieved from: https://www.ncbi.nlm.nih.gov/pubmed/8659319.

Aids Info. 2017, February 24. Understanding HIV/AIDS. Retrieved from: https://aidsinfo.nih.gov/understanding-hiv-aids/fact-sheets/21/51/hiv-treatment--thebasics/.

Asante K.O. \& Oti-Boadi M. 2013. HIV/AIDS knowledge among undergraduate university students: implications for health education programs in Ghana. Afr Health Sci 13(2): 270-277. DOI: 10.4314/ahs.v13i2.11PMCID: PMC3824504. Retrieved from: https://www.ncbi.nlm.nih.gov/pmc/articles/PMC3824504/citedby/ .

Avert 2016. HIV and AIDS in Nigeria. Retrieved from: https://www.avert.org/professionals/hiv-around-world/sub-saharan-africa/nigeria.

Bettman J.R. \& Whan C.P. 1980. Effects of prior knowledge and experience and phase of the choice process on consumer decision processes: A protocol analysis. Journal of Consumer Research 7(1): 234-248. Retrieved from: https://ideas.repec.org/a/oup/jconrs/v7y1980i3p234-48.html.

Brucks M. 1985. The effects of product class knowledge on information search behavior. Journal of Consumer Research 12(1):1-16. Retrieved from: https://www.researchgate.net/publication/24098405_The_Effects_of_Product_Class_K no wledge_on_Information_Search_Behavior. DOI: 10.1086/209031.

Centers for Disease Control and Prevention. 2015. About HIV/AIDS. Retrieved from: https://web.archive.org/web/20160224101946/http://www.cdc.gov/hiv/basics/whatishiv. html. 
Cote A., Sobela F., Dzokoto A., Nzambi K., Asamoah A.C., Labbe A. 2004. Transactional sex is the driving force in the dynamics of HIV in Accra, Ghana. AIDS. 18(1):917-925. Retrieved from: https://www.ncbi.nlm.nih.gov/pubmed/15060439

Ebeniro C.D. 2010. Knowledge and beliefs about hiv/aids among male and female students of Nigerian universities. Journal of comparative research in anthropology and sociology. 1(1):121-131. Retrieved from: http://doctorat.sas.unibuc.ro/wp content/uploads/2010/10/ChiomaEbeniro_Compaso2010.

Ezeonyido J.P.C. 2016. HIV knowledge, intoxication, risky behaviors, and sexual communication among Nigeria University Students. Walden Dissertations and Doctoral Studies. Retrieved from: http://scholarworks.waldenu.edu/dissertations/1888/.

Fiske S.T., Donald R.K., Michael W.L. 1983. The novice and the expert: Knowledge based strategies in political cognition. Journal of Experimental Social Psychology 19(4): 381-400. Retrieved from:

https://www.sciencedirect.com/science/article/pii/002210318390029X.

DOI: https://doi.org/10.1016/0022-1031(83)90029-X

Graesser C.A. \& Glenn V.N. 1982. The impact of a schema on comprehension and memory, in Gordon H. Bower, ed., The Psychology of Learning and Motivation.

New York: Academic Press, 16, 59-109. Retrieved from:

https://www.sciencedirect.com/science/article/pii/S0079742108605472.

DOI: https://doi.org/10.1016/S0079-7421(08)60547-2

Harding A.K., Anadu E.C., Gray L.A., Champeau D.A. 1999. Nigerian university students' knowledge, perceptions, and behaviours about HIV/AIDS: are these students at risk? Perspectives in Public Health. Retrieved from:

http://journals.sagepub.com/doi/abs/10.1177/146642409911900105.

Johnson E.J. \& Edward J.R. 1984. Product familiarity and learning new information. Journal of Consumer Research 11(1): 542-550. Retrieved from:

http://www.acrwebsite.org/volumes/9801/volumes/v08/NA-08.

Jose O., Totona K., Begani A., Andew T., Tombe B., Begani R. 2011. Knowledge, Attitudes and Beliefs on HIV/AIDS among tertiary students in Papua New Guinea. World Journal of AIDS 1(1): 50-61. Retrieved from: http://file.scirp.org/pdf/WJA20110200001 66827421.pdf.

Liesl J.Z. \& Mark E.E. 2013. The importance of awareness and education in prevention and control of RHD. Global Heart 8(3): 235-239. Retrieved from: https://ac.els- cdn.com/S2211816013001154/1-s2.0-S2211816013001154main.pdf? tid=4a7af3c2-1f6e-4645-aec2905a7e83a4f8\&acdnat=1552053240_1995398d450c05985bf6a2cef5915684.

DOI: https://doi.org/10.1016/j.gheart.2013.08.009 
Markowitz S.B. 2007. Environmental and occupational medicine (4th ed.). Philadelphia: p. 745. National Agency for Control of AIDS. 2009. Global AIDS response: Country progress report. Abuja, Nigeria: Federal Republic of Nigeria.

National Agency for Control of AIDS. 2012. Kwara state HIV/AIDS epidemiology and impact analysis. Ilorin, Nigeria.

National Agency for Control of AIDS. 2014. Nigeria prevalence rate.

Retrieved from: https://naca.gov.ng/nigeria-prevalence-rate/

Obermiller C. \& John J.W. 1984. Price effects on choice and perceptions under varying conditions of experience, information, and beliefs in quality differences, in Advances in Consumer Research, Thomas C. Kinnear, ed., Provo Utah: Association for Consumer Research 11(1): 453-458. Retrieved from:

http://www.acrwebsite.org/volumes/6296/volumes/v11/NA-11.

Obisesan K.A., Adeyemo A.A., Fakokunde B.O. 1998. Awareness and use of family planning methods among married women in Ibadan. Nigeria. East Afr Med J. 75(3): 135-138. Retrieved from: https://www.ncbi.nlm.nih.gov/pmc/articles/PMC4111004/.

Odua B.K. \& Akanle F.F. 2008. Knowledge of HIV/AIDS and sexual behavior among the youths in South West Nigeria. Humanity \& Social Sciences Journal. 3 (1): 81-88. Retrieved from: http://www.idosi.org/hssj/hssj3(1)08/10.pdf.

Ogini O.O., Ofodile M.C., Odusanmi D.O., Taiwo A.M. 2015. Awareness and response to Human Immunodeficiency Virus / Acquired Immune Deficiency Syndrome (HIV/AIDS) among University students in Abeokuta, Nigeria. Public Health Research 5(6): 192-197. DOI:10.5923/j.phr.20150506.04. Retrieved from: http://article.sapub.org/10.5923.j.phr.20150506.04.html.

Ojua T.A \& Ishor D.G. 2013. African cultural practices and health implications for Nigeria rural development. International Review of Business and Management Research 2 (1): 176-183. Retrieved from:

http://irmbrjournal.com/papers/1367572222.pdf.

Oppong Asante K. \& Oti-Boadi M. 2013. HIV/AIDS knowledge among undergraduate university students: implications for health education programs in Ghana. African Health Sciences, 13(2): 270-277. Retrieved from:

http://www.bioline.org.br/pdf?hs13039. http://doi.org/10.4314/ahs.v13i2.11.

Oye-Adeniran B.A., Adewole I.F., Umoh A.V.,Oladokun A., Gbadegesin A., \&Ekanem E.E. et al. 2006. Community based study of contraceptive behavior in Nigeria.

Afr J Rep Health 10(2): 90-104. Retrieved from:

https://www.researchgate.net/publication/6584674_Community-

based_Study_of_Contraceptive_Behaviour_in_Nigeria. DOI: $10.2307 / 30032462$ 
Rajesh K., Lorna G., Jerry C.O. 1990. When do the measures of knowledge measure what we think they are measuring? in NA - Advances in consumer Research 17(1): 603608 (eds.), Marvin E. Goldberg, Gerald Gorn and Richard W. Retrieved from: http://acrwebsite.org/volumes/7072/volumes/v17/NA-17.

Sweller J. 1988. Cognitive load during problem solving: Effects on learning, Cognitive Science, 12(1): 257-285. Retrieved from:

https://pdfs.semanticscholar.org/d88c/481743db95687bf9d2861c16cd006f67a0a1.pdf.

World Bank HIV/AIDS. 2002. Prevention and care strategies for HIV. Retrieved from: www.worldbank.org.

World Health Organization. 2015. HIV/AIDS Fact sheet 360 November 2015. Retrieved from:

https://web.archive.org/web/20160217160830/http://www.who.int/mediacentre/factshee ts/fs360/en/.

To cite this article:

Joseph A. Oluyemi, Joseph A. Adejoke, Olokoba L. Bukola, Adekeye Deborah, Popoola Gbenga. 2019.

Knowledge, beliefs and sources of information of HIV among students of a Tertiary Institution in Nigeria. International Journal of Modern Anthropology. 2 (12): 63-78

DOI: http://dx.doi.org/10.4314/ijma.v2i12.2

\section{@(@) $\Theta \Theta$}

This article, as all articles published in this journal, is under The Creative Commons Attribution:

Attribution-NonCommercial-NoDerivatives 4.0 International (CC BY-NC-ND 4.0). https://creativecommons.org/licenses/by-nc-nd/4.0/ 